\title{
Inventory of forest belts on agricultural lands of Streletsky rural settlement of Belgorodsky district of Belgorod region
}

\author{
Anton A. Melentyev* \\ Belgorod State Agricultural University, 1 Vavilova str., Maysky, Belgorod region, Russia, 308503
}

\begin{abstract}
From 2016, on the territory of the Belgorod region, the project 'Formation of a system for maintenance and reproduction of fieldprotective woodlands (forest belts) on agricultural lands in the Belgorod region' is being implemented. The main goal of this project is to ensure safety and maintenance in proper condition of at least 50 thousand hectares of protective woodland (forest belts) on the territory of the Belgorod region by securing responsibility of specific land users and (or) local authorities. Based on the results of this work, materials for calculating the areas of former farms in the Belgorod region were collected and systematized; on the territories of urban and rural settlements of the Belgorod region, on basis of the data obtained, an inventory of field-protective, gully forest belts and forest belts, adjacent to local highways, has to be carried out, an inventory of forest belts adjacent to highways of regional importance has to be carried out, municipal applications for cleaning and mulching forest belts has to be drawn up. Thus, assessment of the state of forest belts of the Belgorod region and their subsequent restoration or revegetation is carried out.
\end{abstract}

\section{Introduction}

Agroforestry zoning and on-farm zoning of agricultural land in need of protection from erosion, deflation and drought is extremely important for successful agriculture, ensuring comprehensive accounting and the most complete use of natural and economic resources, improvement and protection of the environment. Based on the federal scheme of agroforestry zoning in Russia, All-Russian Research Institute of Agroforestry has developed a zoned assortment of trees and shrubs for protective afforestation in rainfed conditions in the main natural and agricultural regions of Russia.

In areas of active manifestation of deflation, dry winds and blizzards, windbreaking forest belts are created. The main principles of their creation are maximum protection of fields from unfavorable factors of the natural environment, improvement of microclimate, hydrological conditions, optimal organization of the territory, and an increase in the yield of agricultural crops. Forest belts, performing a field-protective function and aimed at combating drought, dry winds and soil deflation, are created on arable land along the

\footnotetext{
* Corresponding author : melentev_07@mail.ru
} 
borders of crop rotation fields and crop rotation plots, along irrigation and waste canals, along roads. The main (longitudinal) forest belts are located across the direction of the most harmful winds (dry winds, blizzards), and the auxiliary (transverse) ones are located perpendicular to the main ones. Deviation of the main forest belts from the directions of prevailing winds can be up to $30^{\circ}$.

Stock-regulating forest belts are created mainly on arable lands of near-watershed and, partially, off-grid slopes. Their main purpose is retention and safe discharge of the surface runoff of meltwater and rainwater. In addition, they perform anti-erosion, as well as windbreaking and agro-climatic functions. In order to absorb surface runoff better, runoffregulating strip plantations are combined with ramparts and ditches. Ditches are arranged in the lower aisle of forest belts.

Anti-erosion protective forest plantations on the off-grid and hydrographic funds include ravine, gully, coastal, floodplain forest belts, massive and group plantations in ravines, gullies, on river banks, stony lands, etc. They are designed for a given magnitude of ameliorative effect, using zonal recommendations and standards, and coordinated with the accepted arrangement of the territory and the nature management system. Ravine forest belts are designed in conjunction with the use of the area of ravine slopes. Planted vegetation along the edges of ravines, where there is a threat of erosion of the banks, is created with a width of 9-12 $\mathrm{m}$ and an openwork structure. On the lower edge forest belts are ridged. In all natural zones, gully forest belts are created along the edges of large ravines that are not subject to flattening or afforestation (Fig. 1).

The design of forest reclamation plantations in combination with other protective measures should ensure reduction of erosion processes to permissible limits, taking into account specifics of location and interaction of agricultural, transport, residential, industrial, recreational and other specialized subsystems in a single geographical system. This problem is solved with the help of landscape planning with the development of regional schemes of landscape organization of agricultural territory [1].

\section{Materials and methods}

For the first time in Russia, V.Ya. Lomikovsky planted plots of arable land with tall trees in the Poltava province in 1809. The scientific foundations of field protection afforestation were developed by V.V. Dokuchaev and G.N. Vysotsky at the end of 19th century. At the same time, forest belts were laid in the steppe regions of the European part of Russia. Great importance was attached to forest shelterbelts in the USSR. In the resolution of the Labor and Defense Council 'On combating drought', signed by V.I. Lenin on April 29, 1921, it was said that 'To charge the Central Forestry Department with the responsibility to develop on a national scale work on: a) strengthening of ravines and sands by means of tree plantations, especially in the regions of Saratov, Samara, Tsaritsyn, Astrakhan, Tula and Don regions; b) arrangement of snow collecting strips and hedges; c) afforestation of clearings, burnt-out areas and other treeless areas in arid regions, as well as in the upper reaches and along river banks'. 


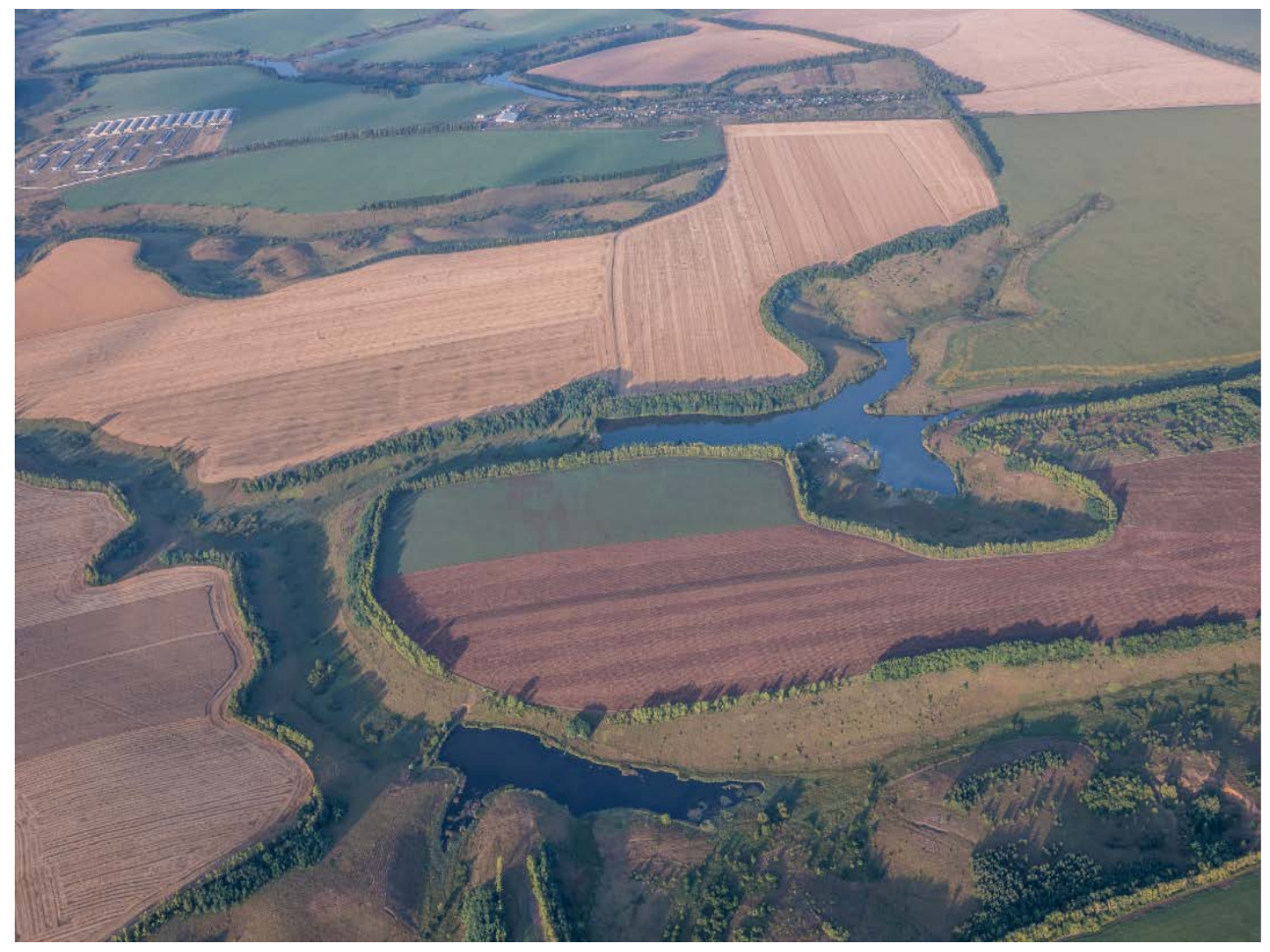

Fig. 1. Anti-erosion protective forest plantations

In the first five-year plan (1929 - 1932), forest belts were planted on an area of 21 thousand hectares, in the second five-year plan (1933 - 1937) - 278 thousand hectares. In the decree of the Council of People's Commissars of the USSR and the Central Committee of the All-Union Communist Party of Bolsheviks of October 26, 1938 'On measures to ensure a sustainable harvest in the arid regions of the southeast of the USSR' a new program was given for growing forests in the steppe. In October 1948, the Council of Ministers of the USSR and the Central Committee of the All-Union Communist Party of Bolsheviks adopted a resolution to create a system of large state protective forest belts. In the USSR, the measures reflected in the 'Stalin's plan for the transformation of nature' were distributed, which was approved by the decree of the Council of Ministers of the USSR and the Central Committee of the All-Union Communist Party of Bolsheviks of October 20, 1948. The plan itself was adopted on the initiative and signed by I.V. Stalin and went down in history as the 'Stalin's plan for the transformation of nature' [2].

The project, calculated for the period of 1949-1965, provided for the creation of 8 large forest state belts in the steppe and forest-steppe regions with a total length of over 5300 kilometers. Calculated up to 1965, the plan for transforming the nature was curtailed by 1956-1959. Many forest belts were cut down. With de-Stalinization of Soviet society, a steady tendency emerged to view the nature-transforming projects carried out in Stalin's times in an exclusively negative aspect.

One of the consequences of the curtailment of this plan and introduction of extensive methods of increasing arable land was that in 1962 - 1963 there was an ecological catastrophe associated with soil erosion on virgin lands, and a food crisis broke out in the USSR.

During the years of perestroika, from 1985, work on the expansion and modernization of the irrigation and forest plantations created in the USSR was discontinued, and the system itself began to collapse. As a result, the water supply of agriculture began to decline 
sharply. In the 1980s, the planting of forests in the amount of 30 thousand hectares per year was still carried out in the forest belts, after 1995 it fluctuated at the level of about 2 thousand hectares. The created forest belts were overgrown.

Thus, the issues of agroforestry development of territories, which were actively introduced in the USSR, ceased to be relevant in the post-Soviet period. Attempts to revive agroforestry by research institutions have so far been unsuccessful due to the lack of government funding [3].

\section{Research issues}

The current state of forest belts is generally unsatisfactory as they are often contaminated with household and industrial waste, damaged by fires, unauthorized felling, diseases and pests. The main part of forest plantations is ownerless, as due to a lack of funds, land surveying has not been carried out, forest plantations have not been registered in the cadastral register, and the registration of ownership has not been done. Forest belts, deprived of supervision and maintenance, need urgent forestry measures. It is noted that $90 \%$ of roadside and dust-proof forest belts are damaged. This became clear after an inventory by the Agro-Industrial Complex Department [4].

At the end of 2019, a bill was proposed in the Belgorod region, which was supposed to determine the person responsible for the proper condition of forest belts and plant pollution. However, since 2020, the concept of ameliorative protective forest plantations has appeared in Russian legislation, and those responsible are assigned to them.

The need to adopt a federal law was dictated by the fact that the legal status of protective forest plantations was not determined, and the issues of their registration and maintenance were not regulated. Forest belts created in Soviet times were ownerless for many years. Trees were illegally sawed for firewood, people got rid of them in order to widen motorways or build something on the roadside. All of this exacerbated environmental problems. Introduction of new rules will make it possible to eliminate these problems to a certain extent. The right holders of land plots are required to ensure maintenance and preservation of ameliorative protective forest plantations. At the same time, in cases where plantations are located on plots that are in state or municipal ownership and are not transferred for use to third-party organizations, these responsibilities are assigned to the authorities.

In the Belgorod region, for the implementation of the project, a roadmap of measures was developed to determine the balance of forest belts in the Belgorod region, approved by the Governor of the Belgorod region Savchenko E.S. dated October 30, 2018.

At the first stage, an inventory of all forest belts on the territory of the Belgorod region was to be completed and a consolidated statement (register) of forest belts was to be formed, indicating the state of the forest belts and the owners and users of the lands adjacent to them. The inventory was carried out by the administrations of all rural settlements. For this, field surveys were carried out with photographic recording of the state of forest belts, drawing up of phototables and inspection reports. Further, cartographic material and a statement (register) of forest belts were compiled for each settlement (Fig. 2). Based on the results of field surveys, a consolidated statement (register) of forest belts for the Streletsky rural settlement was formed. Based on the results of the inventory, the settlement's administration gave recommendations for the subsequent restoration and (or) reclamation of forest belts. 


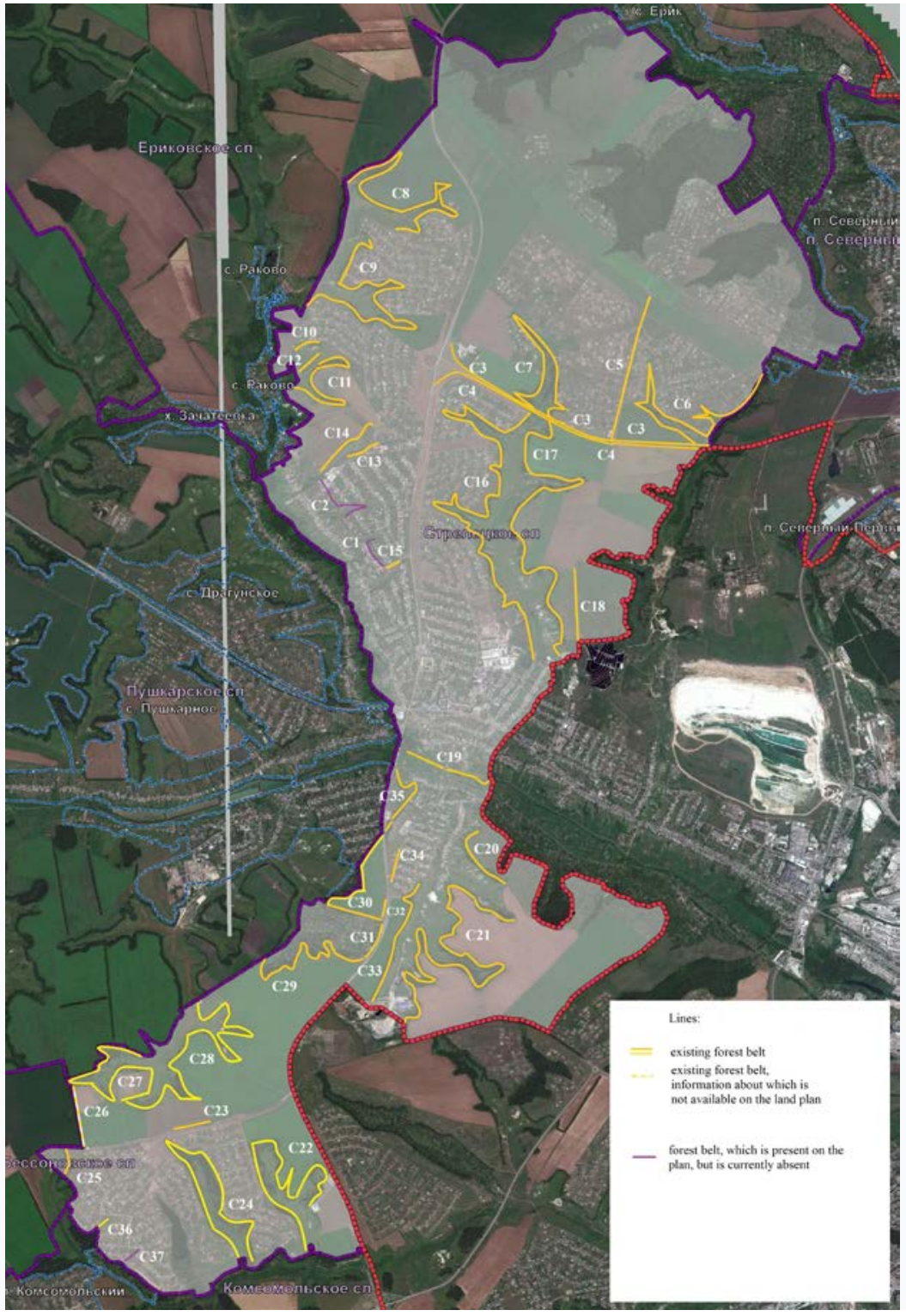

Fig. 2. The territory of Streletsky rural settlement of Belgorod district of Belgorod region.

The layout of forested land plots was developed (Fig. 3).

Further, an application for amending the Land Use and Development Rules (master plan) of settlements has been sent to the Commission on Land Use and Development Rules under the Belgorodsky District Administration, after which work is going to be carried out on land surveying, registration of title documents and transfer of forested ravines to the state forest fund. 


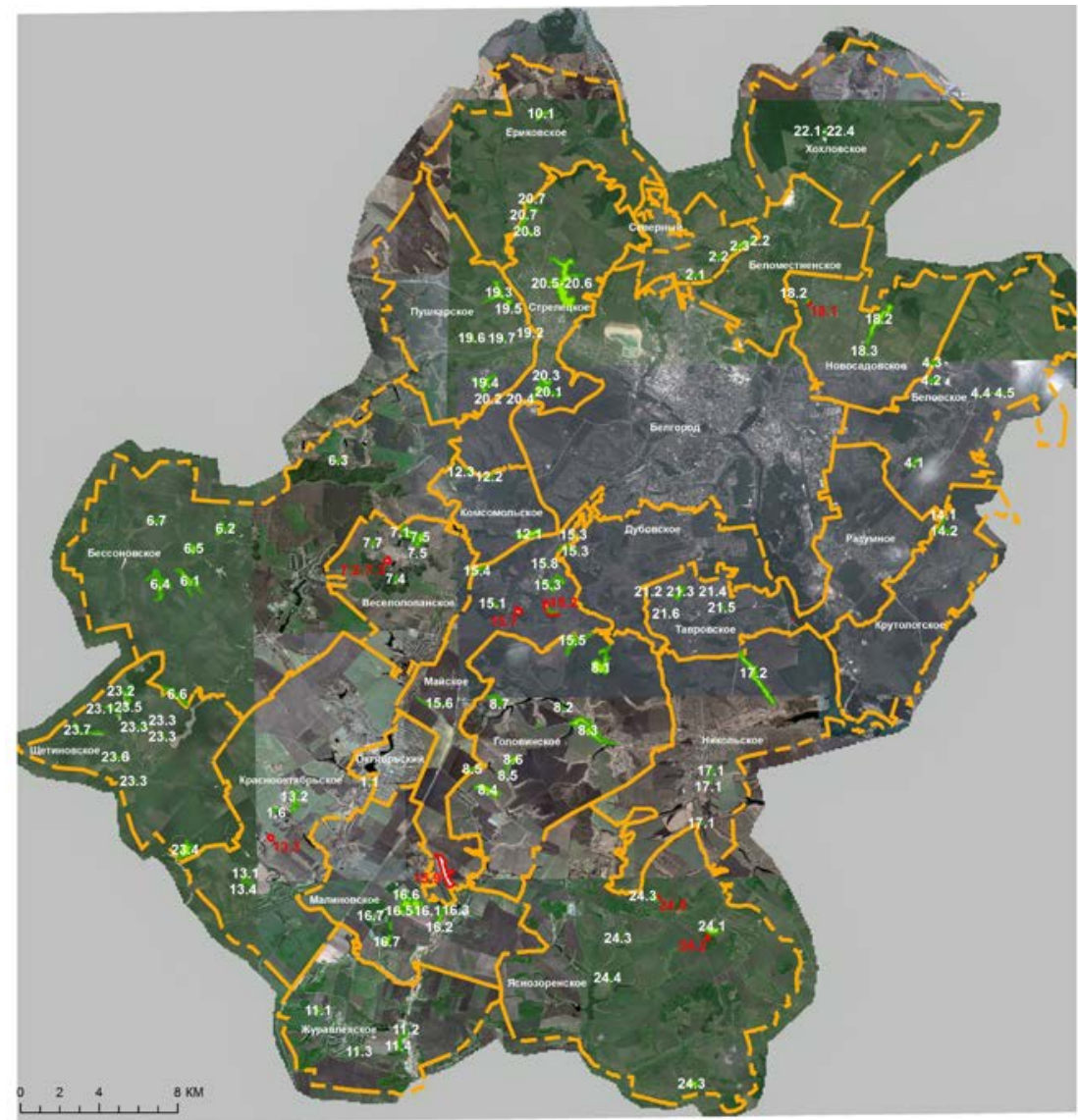

Forested lands

Afforestation proposals

Settlement boundaries

Fig. 3. Layout of land plots afforested under the 'Green Capital' program, as well as proposals for the transfer of individual plots to the forest fund of the Russian Federation on the territory of the Belgorod region.

\section{Conclusion}

The studies carried out to protect soil from erosion, comprehensively improve the agroecological state of lands and increase efficiency of agriculture (using resource-saving technologies) made it possible to develop a project of adaptive landscape farming, which is maximally integrated into the existing industrial and environmental infrastructure of the economy, focused on the differentiated use of various agro-ecological types of land in the real conditions of modern, very difficult financial, economic and material and technical situation. 
Thus, restoration of the system of protective forest belts is one of the main strategic tasks of agriculture and a guarantee of Russia’s sustainable development in the future.

\section{References}

1. Erusalimsky V.I., Ryzhkov V.A. Mnogofunktsionalnaya rol zaschitnykh lesnykh nasazhdeniy [The multifunctional role of protective forest plantations]. Bulletin of the Soil Institute named after V.V. Dokuchaev. 2017, pp. 121-137.

2. Cherkasov G.N., Akimenko A.S. Modeli adaptivno-landshaftnykh sistem zemledeliya dlya osnovnykh prirodno-sel'skokhozyaystvennykh regionov strany [Models of adaptive landscape farming systems for the main natural and agricultural regions of the country]. Kursk, 2005, 80 p.

3. Kosolapov V.M., Trofimov I.A., Trofimova L.S., Yakovleva E.P. Agrolandshafty Tsentral'nogo Chernozem'ya [Agrolandscapes of the Central black earth region]. Moscow, Nauka Publ., 2015, 198 p.

4. Shaidarov V.S., Melentiev A.A. Problems of conservation of agricultural forests. Gorinskiye chteniya. Nauka molodykh - innovatsionnomu razvitiyu APK. [Gorin Readings. Science of the young - to the innovative development of the agro-industrial complex]. Materials of the International Student Scientific Conference Gorin Readings. 2019, pp. 114-115. 